\title{
Trait-based Measure of Dehumanization: Adaptation for the Portuguese population
}

\author{
Lúcia Campos $^{1}$, Ana Louceiro ${ }^{1}$, Tânia Brandão ${ }^{2}$ \& Sónia Bernardes ${ }^{1}$ \\ ${ }^{1}$ Instituto Universitário de Lisboa (ISCTE-IUL) \\ 2 Universidade Autónoma de Lisboa
}

\begin{abstract}
Although dehumanization (i.e., the denial of full humanness to others; Haslam, 2006) has been a frequent subject in social psychology, a set of traits designed to evaluate this phenomenon has not been validated to the Portuguese population. The main purpose of this study was to translate, culturally adapt and validate a set of dehumanization traits proposed by Haslam and colleagues (Haslam \& Bain, 2007; Haslam, Bain, Douge, Lee \& Bastian, 2005), which measure both the denial of uniquely human and human nature traits. A sample of 597 individuals $\left(M_{\text {age }}=40.83 ; S D=11.50\right)$ were asked to rate a set of 52 traits on how much they perceived each as a characteristic of human nature and human uniqueness, as well as its desirability. T-tests were conducted to distinguish between low and high rated traits in each dimension, and to construct clusters of traits that differ in each dimension. We successfully provide a measure containing positive traits in both senses of humanness dimensions; however, we were only able to validate a human uniqueness measure with negative valence. Implications of this measure for future research on dehumanization processes are discussed.
\end{abstract}

\section{Keywords: Dehumanization; validation; traits; translation; portuguese.}

Medida de desumanização baseada em traços: Adaptação para a população portuguesa: 0 fenómeno da desumanização (i.e., a negação de humanidade a terceiros; Haslam, 2006) tem sido um tópico frequentemente estudado na Psicologia Social; no entanto, um conjunto de traços para avaliar este fenómeno não foi ainda validado para a população portuguesa. Este estudo teve como objetivo traduzir, adaptar e validar, para a população portuguesa, o conjunto de traços proposto por Haslam e colegas (Haslam \& Bain, 2007; Haslam, Bain, Douge, Lee \& Bastian, 2005), que medem a negação de traços de duas dimensões: "uniquely human" e "human nature". Uma amostra de 597 participantes $\left(M_{\text {idade }}=40.83 ; D P=\right.$ 11.50) avaliaram em que medida percebiam cada um de 52 traços como uma característica da natureza humana e unicamente humanos, bem como a sua desejabilidade. Foram conduzidos testes de forma a distinguir entre traços com avaliações baixas e altas em cada dimensão, e construídos grupos de traços que diferenciam entre cada uma das dimensões. Apresentamos a validação de uma medida com valência positiva que distingue entre ambas as dimensões de "humanness"; no entanto, foi apenas possível validar uma medida de "human uniqueness" com valência negativa. As implicações desta medida para a investigação futura são abordadas.

\section{Palavras-chave: Desumanização; validação; traços; tradução; português.}

Claiming that other people are animals or objects seems to be one of the worst categorization errors and probably one of the most shocking statements one can make. It is not so uncommon though. Our history as a species is full of examples of groups being perceived as not human or at least as less than human. Slaves were perceived as only a fraction of a complete person (U.S. Const., art. I, § 2), Nazi propaganda deemed Jews "rats" or "vermin" (e.g., Der Ewige Jude, 1940) and Hutus referred to Tutsis as "cockroaches" (e.g., Ngeze, 1993). Even recently, immigrants are still likened to invasive pests (e.g., Wing, 2013), sex offenders are sometimes compared to beasts (e.g., Reynolds, 2012) and homeless people are perceived as objects (e.g., as internet hotspots; Wortham, 2012).

Whereas history has been providing many examples of dehumanization for a long time, social psychology has only recently started to explore the reasons why granting equal humanness to all human beings is so difficult. In the last decade, several theories have studied the phenomenon of dehumanization, extending its original conception outside the domains of overt conflict since it can occur in any

\footnotetext{
${ }^{1}$ Correspondence address: Lúcia Campos, Av. Forças Armadas, Ed. ISCTE, 1649-026 Lisboa, Portugal. E-mail: lucia_campos@iscte-iul.pt, The authors gratefully acknowledge the financial support of Fundação para a Ciência e Tecnologia (FCT-Portugal), through the research project entitled "On the Pains of Social Standing: Understanding the role of patient social status on nurses' pain assessment and management practices" (PTDC/MHC-PSC/2041/2014; Principal Investigator: Sónia F. Bernardes). The authors have no conflicts of interest to declare.
} 
interpersonal or intergroup context (Bastian, Jetten, \& Haslam, 2014; Haslam \& Loughnan, 2014). Indeed, researchers have explored the role of dehumanization in medicine/health care, organizational settings, and technology, among others (e.g., Christoff, 2014; Diniz, Bernardes \& Castro, 2019; Haque \& Waytz, 2012; Haslam, 2006).

In this paper, we intended to provide an adequate measure to study the dehumanization phenomenon in the Portuguese context, by translating, culturally adapting and validating a set of traits that comprise the two dimensions of dehumanization as proposed by Haslam and colleagues: human nature and human uniqueness, as well as traits perceived desirability (Haslam \& Bain, 2007; Haslam, Bain, Douge, Lee \& Bastian, 2005). This will contribute to improve the study of dehumanization within the Portuguese context, as such culturally validated measure will control for language and cultural differences in meanings associated to dehumanization traits (Bain et al., 2012; McCrae \& Costa, 1997). This will ultimately provide a measure tailored to the specific Portuguese context, as well as allow for more accurate cross-cultural comparisons.

\section{Conceptualizing Dehumanization}

Dehumanization has been examined, essentially, from the point of view of two-dimensional models of humanness that differentiate between animalistic and mechanistic dehumanization (Haslam, 2006; Leyens et al., 2000). In the first model, proposed by Leyens et al. (2000; 2001) infra-humanization represents the tendency of people to consider their ingroup as fully human while considering other groups as less human or more animal-like, attributing them fewer uniquely human emotions. The main emphasis of this model is on the distinction between primary or non-uniquely human emotions, considered to be shared with other animals (e.g., surprise and fear) and secondary or uniquely human emotions that are only expressed by human beings (e.g., regret and enthusiasm). Several studies within this model have shown that individuals have the tendency to attribute more secondary emotions (whether positive or negative) to their ingroup than to outgroups, but they do not differentially attribute primary emotions (for reviews see Leyens et al., 2007; Vaes et al., 2012). Infra-humanization theory has been pioneer in stressing the relative nature of the dehumanization phenomenon by moving it from the realm of intergroup conflict to our everyday lives as a pervasive phenomenon. However, it is limited in the sense that it only focuses on the distinction between animals and humans.

More recently, Haslam's dual model of humanness (Haslam, 2006) emphasized that human-animal distinction is only one of two dimensions through which humanness might be understood. Therefore, going beyond the distinction between primary and secondary emotions, Haslam et al. (2005) have considered human traits. In this model, humanness can be understood as comprised by characteristics that are uniquely human (e.g., civility, refinement, moral sensibility, rationality and maturity) and define boundaries between human and non-human animals (Li, Leidner \& Castano, 2014), and by other characteristics that represent the core essence of human nature (e.g., warmth, cognitive openness, agency, and depth), which we share with other species but that set us apart from objects or machines (Haslam, 2006; Haslam, Loughnan, Kashima \& Bain, 2009).

\section{Measuring Human Nature and Human Uniqueness}

Drawing upon Haslam and colleagues' conceptual and operationalization contributions (Bastian \& Haslam, 2010; Haslam \& Bain, 2007; Haslam et al., 2005), we set forth to propose a trait-based measure of human uniqueness and human nature culturally adapted for the Portuguese context. Admittedly, other types of measures of dehumanisation could have been validated in this study. For instance, the human/animalrelated words measure used by Viki and colleagues (2006) would be less sensitive to language, and therefore easier to use in different contexts. However, this measure does not capture the different dimensions of humanness. As it is comprised of human words such as "citizens" and "sophisticated" it has been used to study infrahumanisation, because it distinguishes between humans and animals, but lacks a dimension of human nature, and thus disregards an important part of the dehumanization phenomenon.

Culturally adapting and validating a trait-based measure presents itself as more challenging, given that the meaning of traits tends to be less consistent across social and cultural contexts (Church et al., 2008). However, Haslam and colleagues' trait-based measure of humanness was chosen because it not only encompasses both animalistic and mechanistic dimensions, but it is also suitable for interpersonal and intergroup levels of humanness attribution.

In order to develop an instrument capable of assessing both uniquely human and human nature characteristics, Haslam and colleagues (2005) asked participants to complete a questionnaire in which they rated a list of personality descriptors on a set of items. Eighty descriptors were used, including 60 traits (6 from each pole of each factor) sampled from the Five Factor Model, a taxonomy for personality traits that conceptualizes five main personality factors, i.e., Openness, Conscientiousness, Extraversion, 
Agreeableness, and Neuroticism (Costa \& McCrae, 1992) and 20 value terms sampled from Schwartz's (1992) value taxonomy. The authors assessed the two distinct senses of humanness: uniquely human ("This characteristic is experienced solely by human beings and is not experienced by animals") and human nature ("This characteristic is an aspect of human nature"). They also assessed desirability ("This characteristic is desirable") as well as essentialist beliefs, immutability, prevalence, universality, age of emergence, cognition, morality and social learning. Characteristics understood to be aspects of human nature were considered as relatively consistent across situations, to be deeply rooted or inherent within the personality, and to be inductively potent (Haslam, Bastian, \& Bisset, 2004). However, human nature characteristics were not judged as less mutable than others and were also considered as relatively emotional, desirable, prevalent, universal and emerging at a relatively early age, consistent with the view that human nature is understood to be prescriptively and descriptively normative and embodied in affective dispositions. In contrast, characteristics understood to be uniquely human were judged to be relatively infrequent or atypical and culturally specific, as well as emerging later in child development (Haslam et al., 2005).

The two forms of dehumanization result from the denial of each of these two senses of humanness: mechanistic dehumanization, that occurs when persons or groups are denied human nature traits and are likened to machines; and animalistic dehumanization, that refers to when persons or groups are deprived of uniquely human traits and are compared to animals (Li, Leidner \& Castano, 2014). Haslam and colleagues developed a measure capable of assessing both of these forms, comprised by 40 traits that vary in their desirability and that discriminate between low and high human uniqueness, and low or high human nature; they found substantial empirical support for this dual view of dehumanization (see Haslam \& Loughnan, 2014). Research has often shown that the attribution of one sense of humanness is not correlated with the other sense of humanness, suggesting that both judgments are indeed independent or complementary (e.g. Bain, Vaes, Haslam, Kashima, \& Guan, 2012).

To the best of our knowledge, there seem to be no published studies specifically aiming at the cultural adaptation and validation of measures of dehumanization in the Portuguese context. Indeed, although there is Portuguese research on dehumanization processes (e.g., Lima \& Vala, 2004; Louceiro, 2016; Miranda, Gouveia-Pereira \& Vaes, 2014), these studies have solely translated the original measures and used them to test their hypotheses but did not conduct nor report findings on the psychometric properties of these measures. This is an important gap that limits the conclusions drawn about dehumanization and makes it difficult to compare findings across studies.

Therefore, the goal of this study was to provide a Portuguese trait-based measure of humanness that comprises both human nature and human uniqueness dimensions by considering the perceived desirability of traits. Replicating the original methodology described by Haslam, Bain, Douge, Lee and Bastian (2005) used for the development of the two dimensions of humanness, we intended to culturally adapt and validate the traits developed by Haslam and Bain (2007) and Bastian and Haslam (2010).

\section{METHOD}

\section{Participants}

Participants were recruited between May and October 2017. In total, 1412 individuals accessed an online questionnaire; as consent was mandatory to proceed to the questionnaire, 19 individuals who did not give their consent were not included in the study. Additionally, 10 participants were removed as their nationality was not Portuguese and 785 were removed as they did not report information regarding their nationality (non-Portuguese nationality was an exclusion criteria, and all participants who did not provide an answer to this question, which appeared at the end of the questionnaire, were removed from the analysis, regardless of their completion of the questionnaire). This dropout rate goes in line with research on dropout rates in online questionnaires - see Dodge and Chapman, 2018. Data from one participant was also deemed invalid, due to the invariability of the answers and the short response time (less than two minutes).

The final sample consisted of 597 Portuguese participants (76\% women), aged between 18-67 years $(M=40.83 ; S D=11.50)$. Most participants $(46.4 \% ; \mathrm{n}=277)$ had a bachelor's degree, while $29.8 \%(\mathrm{n}=178)$ had an education level below the higher education.

\section{Set of traits: dependent variables}

Fifty-two traits were included, forty of which were those presented in Haslam and Bain (2007). Additionally, twelve traits were added, based on the items used by Bastian and Haslam (2010); these items refer to sentences that include Human Nature and Human Uniqueness traits. We isolated the traits and included them, as they had the same theoretical background and were also used by the original authors to 
assess the two forms of dehumanization. The traits as well as their translation to Portuguese are presented in Table 1. Three researchers independently made translation suggestions for each trait and, after discussion, they reached consensus. Then, two bilingual (English and Portuguese) speakers made a retroversion, and a final Portuguese version of the traits was achieved.

Table 1. Dehumanization traits, corresponding Portuguese translation and corresponding original dimensions.

\begin{tabular}{|c|c|c|c|c|}
\hline Dehumanization Traits & Portuguese Translation & Desirability & Human Uniqueness & Human Nature \\
\hline Ambitious & Ambicioso & High & High & High \\
\hline Analytic & Analítico & & & \\
\hline Imaginative & Imaginativo & & & \\
\hline Passionate & Apaixonado & & & \\
\hline Sympathetic & Compreensivo & & & \\
\hline Rational* & Racional* & & & \\
\hline Logical* & Lógico* & & & \\
\hline Broadminded & De mente aberta & High & High & Low \\
\hline Conscientious & Consciencioso & & & \\
\hline Humble & Humilde & & & \\
\hline Polite & Educado & & & \\
\hline Thorough & Minucioso & & & \\
\hline Educated* & Culto* & & & \\
\hline Refined* & Refinado* & & & \\
\hline Sophisticated* & Sofisticado* & & & \\
\hline Active & Activo & High & Low & High \\
\hline Curious & Curioso & & & \\
\hline Friendly & Amigável & & & \\
\hline Helpful & Prestável & & & \\
\hline Fun-loving & Gosta de diversão & & & \\
\hline Warm* & Caloroso* & & & \\
\hline Sensitive* & Sensível* & & & \\
\hline Receptive* & Receptivo* & & & \\
\hline Emotional* & Emotivo* & & & \\
\hline Contented & Satisfeito & High & Low & Low \\
\hline Comfortable & À vontade & & & \\
\hline Even-tempered & Tranquilo & & & \\
\hline Relaxed & Relaxado & & & \\
\hline Selfless & Abnegado & & & \\
\hline Frivolous & Frívolo & Low & High & High \\
\hline High-strung & Irritável & & & \\
\hline Insecure & Inseguro & & & \\
\hline Irresponsible & Irresponsável & & & \\
\hline Reserved & Reservado & & & \\
\hline Disorganized & Desorganizado & Low & High & Low \\
\hline Hard-hearted & Insensível & & & \\
\hline Ignorant & Ignorante & & & \\
\hline Rude & Mal-educado & & & \\
\hline Stingy & Mesquinho & & & \\
\hline Superficial* & Superficial* & & & \\
\hline Cold* & Frio* & & & \\
\hline Mechanical* & Mecânico* & & & \\
\hline
\end{tabular}


Table 1. Dehumanization traits, corresponding Portuguese translation and corresponding original dimensions (Cont.)

\begin{tabular}{lllll}
\hline Dehumanization Traits & Portuguese Translation & Desirability & Human Uniqueness & Human Nature \\
\hline Impatient & Impaciente & Low & Low & High \\
Impulsive & Impulsivo & & \\
Jealous & Ciumento & & \\
Nervous & Nervoso & & \\
Shy & Tímido & Low & Low & \\
\hline Passive & Passivo & & Low \\
Simple-minded & Simples de espírito & & \\
Timid & Hesitante & & \\
Uncooperative & Não cooperante & & \\
Unemotional & Não emotivo & & \\
\hline Unmarked traits were proposed by Haslam \& Bain (2007) & & \\
$*$ Traits drawn from Bastian \& Haslam (2010) & &
\end{tabular}

Participants were asked to rate each trait on one of the three dimensions mentioned above, which were randomly presented, so that each participant rated only one dimension. For the rating of Desirability, the question asked was "To what extent do you agree that this characteristic is desirable or positive, that is, this characteristic is one that people generally want to have?"; to assess Human Uniqueness, participants were asked "To what extent do you agree that this characteristic is uniquely human, that is, it does not apply to other animal species?".

Lastly, to evaluate Human Nature, the question "To what extent do you agree that this characteristic is an aspect of human nature, that is, it is an innate characteristic in human beings?". This last phrase (underlined) was added in relation to the original question (Haslam et al., 2004) to clarify participants on what was meant by human nature; to test its face validity, a small number of people were asked to evaluate it in terms of its purpose and clarity. For the three questions, the answers were provided on a 7-point Likert scale, ranging from 1 ("Totally disagree") to 7 ("Totally agree").

\section{Procedure}

Data was collected using the online software Qualtrics. A recruitment email, containing the survey link, was sent to City Halls, public libraries, firefighter corporations, Civil Protection departments, GeneralSecretariats of the Portuguese Ministries, police forces, private security companies, several branches of the Portuguese Armed Forces, trade unions, and public schools, where these entities were asked to distribute the questionnaire to their collaborators.

The study was presented in the first page of the survey, as an impression formation research aiming to explore how people form impressions drawing upon certain characteristics. Informed consent was required to proceed to the survey. Participants were then randomly assigned to one of the three dimensions; 172 participants evaluated the traits in the Desirability dimension, 142 in the Human Uniqueness (HU), and 102 in the Human Nature (HN) dimension. The presentation order of the traits was also randomised.

After rating the traits, sociodemographic data was collected (e.g., sex, age, nationality). Additionally, participants were thanked and those who were interested in knowing more about the study could leave their email address, in order to be debriefed about the study's objectives and results.

\section{Data Analyses}

All analyses were performed using SPSS version 23 (SPSS, Inc., Chicago, IL, USA). Descriptive analyses of the traits were conducted to identify traits rated as low and high in each dimension. In a second step, one sample t-tests were conducted as to identify traits rated lower, equal or higher than the middle point of the scale in each dimension. Given that the means of the traits on desirability had a high dispersion (i.e., varied greatly across all scale points), analyses were conducted separately on high and low desirability traits.

Lastly, as done in Haslam's study (Haslam et al., 2005), traits were clustered to form eight groups (four groups with high desirability traits, and four groups with low desirability traits), and paired samples t-tests were conducted to confirm the differences on Human Uniqueness (HU) and Human Nature (HN) in each of the eight groups (Group 1: high HU and high HN, Group 2: high HU and low HN, Group 3: low HU and high HN, Group 4: low HU and low HN). A significance level of 0.01 was assumed for all analyses. 


\section{RESULTS}

\section{Descriptive Statistics and One-Sample t-tests}

As mentioned above, since ratings on the Desirability dimension were too disperse, clusters were not consistent in their desirability ratings and, thus, desirability was not considered in the paired-sample ttests; instead, a t-test was conducted to contrast traits desirability against the midpoint of the scale, and thus distinguish between positive and negative desirability traits. As for the traits added to the original method, the same t-tests against the midpoint were used to determine their HU and HN rating distribution.

Desirability Dimension. Descriptive statistics and one sample t-tests are presented in Table 2. All traits registered answers in all scale points, except for Comfortable, Logical, Conscientious, Sympathetic and Polite, where the lowest value registered was 2 . The trait with the lowest mean was Rude, and the highest rated trait was Polite. All traits matched the original desirability ratings (Haslam et al, 2005), except for Selfless (originally was rated as high in desirability, but in the present sample was rated as having low desirability).

Table 2. Descriptive statistics and one-sample t-test against the middle point of the scale (4) of the Desirability dimension.

\begin{tabular}{|c|c|c|c|c|c|c|c|c|c|c|c|c|}
\hline & $z$ & $\sum_{\Sigma}^{\Xi}$ & 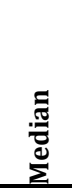 & $\frac{0}{\tilde{g}}$ & के & 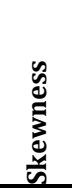 & 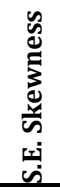 & 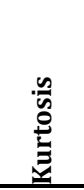 & 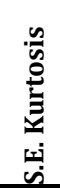 & 志 & 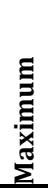 & 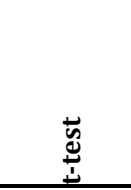 \\
\hline Rude & 172 & 1.72 & 1.00 & 1 & 1.45 & 2.43 & .19 & 5.27 & .37 & 1 & 7 & $-20.64^{* * *}$ \\
\hline Ignorant & 172 & 1.77 & 1.00 & 1 & 1.46 & 2.18 & .19 & 4.13 & .37 & 1 & 7 & $-20.07^{* * *}$ \\
\hline Stingy & 172 & 1.85 & 1.00 & 1 & 1.41 & 2.04 & .19 & 3.92 & .37 & 1 & 7 & $-19.97^{* * *}$ \\
\hline High-strung & 172 & 1.97 & 2.00 & 1 & 1.34 & 1.74 & .19 & 2.77 & .37 & 1 & 7 & $-19.80^{* * *}$ \\
\hline Irresponsible & 172 & 1.99 & 1.00 & 1 & 1.67 & 1.79 & .19 & 2.15 & .37 & 1 & 7 & $-15.72^{* * *}$ \\
\hline Disorganized & 172 & 2.08 & 2.00 & 1 & 1.47 & 1.67 & .19 & 2.52 & .37 & 1 & 7 & $-17.16^{* * *}$ \\
\hline Uncooperative & 172 & 2.09 & 1.50 & 1 & 1.49 & 1.49 & .19 & 1.44 & .37 & 1 & 7 & $-16.84^{* * *}$ \\
\hline Hard-hearted & 172 & 2.16 & 2.00 & 1 & 1.41 & 1.40 & .19 & 1.50 & .37 & 1 & 7 & $-17.12^{* * *}$ \\
\hline Insecure & 172 & 2.18 & 2.00 & 1 & 1.54 & 1.57 & .19 & 1.85 & .37 & 1 & 7 & $-15.46^{* * *}$ \\
\hline Frivolous & 172 & 2.30 & 2.00 & 1 & 1.50 & 1.19 & .19 & .95 & .37 & 1 & 7 & $-14.91^{* * *}$ \\
\hline Cold & 172 & 2.37 & 2.00 & 1 & 1.45 & 1.06 & .19 & .57 & .37 & 1 & 7 & $-14.77^{* * *}$ \\
\hline Nervous & 172 & 2.40 & 2.00 & 2 & 1.50 & 1.25 & .19 & 1.00 & .37 & 1 & 7 & $-13.99 * * *$ \\
\hline Impatient & 172 & 2.45 & 2.00 & 2 & 1.50 & 1.22 & .19 & .97 & .37 & 1 & 7 & $-13.61^{* * *}$ \\
\hline Superficial & 172 & 2.45 & 2.00 & 1 & 1.63 & 1.22 & .19 & .74 & .37 & 1 & 7 & $-12.41^{* * *}$ \\
\hline Jealous & 172 & 2.47 & 2.00 & 2 & 1.50 & 1.27 & .19 & 1.38 & .37 & 1 & 7 & $-13.37^{* * *}$ \\
\hline Unemotional & 172 & 2.54 & 2.00 & 1 & 1.54 & .83 & .19 & -.11 & .37 & 1 & 7 & $-12.44^{* * *}$ \\
\hline Timid & 172 & 2.63 & 2.00 & 2 & 1.49 & .96 & .19 & .55 & .37 & 1 & 7 & $-12.02^{* * *}$ \\
\hline Passive & 172 & 2.95 & 3.00 & 1 & 1.78 & .67 & .19 & -.52 & .37 & 1 & 7 & $-7.73^{* * *}$ \\
\hline Shy & 172 & 2.97 & 3.00 & 3 & 1.43 & .51 & .19 & -.06 & .37 & 1 & 7 & $-9.42^{* * *}$ \\
\hline Impulsive & 172 & 3.25 & 3.00 & 4 & 1.61 & .32 & .19 & -.53 & .37 & 1 & 7 & $-6.10^{* * *}$ \\
\hline Mechanical & 172 & 3.32 & 3.00 & 2 & 1.64 & .34 & .19 & -.69 & .37 & 1 & 7 & $-5.44^{* * *}$ \\
\hline Selfless & 172 & 3.85 & 4.00 & 4 & 1.77 & .04 & .19 & -.83 & .37 & 1 & 7 & -1.08 \\
\hline Reserved & 172 & 3.99 & 4.00 & 4 & 1.38 & .05 & .19 & .09 & .37 & 1 & 7 & -.06 \\
\hline Simple-minded & 172 & 4.41 & 5.00 & 7 & 2.01 & -.26 & .19 & -1.18 & .37 & 1 & 7 & $2.70^{* * *}$ \\
\hline Relaxed & 172 & 4.47 & 5.00 & 5 & 1.79 & -.29 & .19 & -.79 & .37 & 1 & 7 & $3.41^{* * *}$ \\
\hline Thorough & 172 & 4.72 & 5.00 & 5 & 1.40 & -.42 & .19 & .03 & .37 & 1 & 7 & $6.72^{* * *}$ \\
\hline Refined & 172 & 4.92 & 5.00 & 4 & 1.55 & -.53 & .19 & -.04 & .37 & 1 & 7 & $7.79 * * *$ \\
\hline Emotional & 172 & 4.92 & 5.00 & 4 & 1.45 & -.12 & .19 & -.80 & .37 & 1 & 7 & $8.36^{* * *}$ \\
\hline
\end{tabular}


Table 2. Descriptive statistics and one-sample t-test against the middle point of the scale (4) of the Desirability dimension (Cont.)

\begin{tabular}{|c|c|c|c|c|c|c|c|c|c|c|c|c|}
\hline & $z$ & $\underset{\Sigma}{\tilde{\Xi}}$ & 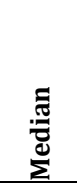 & $\begin{array}{l}\stackrel{0}{0} \\
\Sigma \\
\Sigma\end{array}$ & के & \begin{tabular}{l}
$\mathscr{d}$ \\
\multirow{2}{*}{} \\
$\frac{y}{5}$
\end{tabular} & 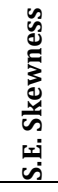 & $\stackrel{n}{0}$ & 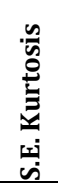 & $\begin{array}{l}\Xi \\
\Xi \\
\Xi \\
\Xi\end{array}$ & 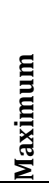 & $\stackrel{\breve{d}}{\Delta}$ \\
\hline Analytic & 172 & 4.97 & 5.00 & 5 & 1.43 & -.38 & .19 & -.31 & .37 & 1 & 7 & $8.82^{* * *}$ \\
\hline Ambitious & 172 & 5.16 & 5.00 & 5 & 1.36 & -.42 & .19 & -.03 & .37 & 1 & 7 & $11.18^{* * *}$ \\
\hline Sophisticated & 172 & 5.19 & 5.00 & 7 & 1.43 & -.46 & .19 & -.36 & .37 & 1 & 7 & $10.92^{* * *}$ \\
\hline Curious & 172 & 5.25 & 5.00 & 5 & 1.37 & -.69 & .19 & .55 & .37 & 1 & 7 & $11.94^{* * *}$ \\
\hline Sensitive & 172 & 5.27 & 5.50 & 6 & 1.36 & -.47 & .19 & -.53 & .37 & 1 & 7 & $12.28^{* * *}$ \\
\hline Comfortable & 172 & 5.36 & 6.00 & 6 & 1.30 & -.49 & .19 & -.48 & .37 & 2 & 7 & $13.71^{* * *}$ \\
\hline Fun-loving & 172 & 5.52 & 6.00 & 6 & 1.29 & -.67 & .19 & .03 & .37 & 1 & 7 & $15.47^{* * *}$ \\
\hline Humble & 172 & 5.70 & 6.00 & 7 & 1.47 & -1.16 & .19 & 1.00 & .37 & 1 & 7 & $15.19^{* * *}$ \\
\hline Logical & 172 & 5.73 & 6.00 & 6 & 1.20 & -.81 & .19 & .06 & .37 & 2 & 7 & $18.87^{* * *}$ \\
\hline Passionate & 172 & 5.76 & 6.00 & 7 & 1.31 & -1.11 & .19 & 1.17 & .37 & 1 & 7 & $17.63^{* * *}$ \\
\hline Contented & 172 & 5.77 & 6.00 & 7 & 1.37 & -.94 & .19 & .21 & .37 & 1 & 7 & $16.93^{* * *}$ \\
\hline Warm & 172 & 5.77 & 6.00 & 7 & 1.32 & -.95 & .19 & .24 & .37 & 1 & 7 & $17.55^{* * *}$ \\
\hline Rational & 172 & 5.78 & 6.00 & 7 & 1.21 & -.91 & .19 & .86 & .37 & 1 & 7 & $19.40^{* * *}$ \\
\hline Even-tempered & 172 & 5.79 & 6.00 & 7 & 1.29 & -1.14 & .19 & .96 & .37 & 1 & 7 & $18.14^{* * *}$ \\
\hline Receptive & 172 & 5.83 & 6.00 & 7 & 1.24 & -1.28 & .19 & 1.89 & .37 & 1 & 7 & $19.33^{* * *}$ \\
\hline Imaginative & 172 & 5.91 & 6.00 & 7 & 1.15 & -1.16 & .19 & 1.83 & .37 & 1 & 7 & $21.83^{* * *}$ \\
\hline Broadminded & 172 & 5.91 & 6.00 & 7 & 1.23 & -1.18 & .19 & 1.15 & .37 & 1 & 7 & $20.34^{* * *}$ \\
\hline Helpful & 172 & 5.95 & 6.00 & 7 & 1.24 & -1.30 & .19 & 1.63 & .37 & 1 & 7 & $20.54^{* * *}$ \\
\hline Active & 172 & 5.99 & 6.00 & 7 & 1.13 & -1.41 & .19 & 2.71 & .37 & 1 & 7 & $23.10^{* * *}$ \\
\hline Conscientious & 172 & 6.00 & 6.00 & 7 & 1.18 & -1.11 & .19 & .71 & .37 & 2 & 7 & $22.14^{* * *}$ \\
\hline Sympathetic & 172 & 6.06 & 6.00 & 7 & 1.06 & -1.06 & .19 & .58 & .37 & 2 & 7 & $25.38^{* * *}$ \\
\hline Friendly & 172 & 6.08 & 6.00 & 7 & 1.16 & -1.47 & .19 & 2.38 & .37 & 1 & 7 & $23.60^{* * *}$ \\
\hline Educated & 172 & 6.26 & 7.00 & 7 & 1.12 & -2.13 & .19 & 5.84 & .37 & 1 & 7 & $26.52^{* * *}$ \\
\hline Polite & 172 & 6.35 & 7.00 & 7 & 1.01 & -1.73 & .19 & 2.78 & .37 & 2 & 7 & $30.67^{* * *}$ \\
\hline
\end{tabular}

${ }^{*} p<0.1 ;{ }^{* *} p \leq 0.05 ;{ }^{* * *} p \leq 0.01$

Human Uniqueness Dimension. Descriptive statistics and one sample t-tests are presented in Table 3. Human Uniqueness ratings varied in all scale points, for all traits. The lowest rated trait was Curious, and the highest rated trait was Educated. There were eight mismatched traits, when compared to the rating in the original sample (Haslam et al., 2005). High-strung, Insecure, Mechanical, Reserved, Passionate and Cold, originally considered traits high in Human Uniqueness, were rated as low in Human Uniqueness in the present sample. Conversely, there were two traits, originally considered low in Human Uniqueness, that were rated as high in this sample: Helpful and Simple-minded. 
Table 3. Descriptive statistics and one-sample t-test against the middle point of the scale (4) of the Human Uniqueness dimension.

\begin{tabular}{|c|c|c|c|c|c|c|c|c|c|c|c|c|}
\hline & $z$ & 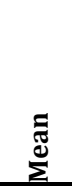 & 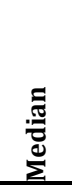 & $\begin{array}{l}0 \\
\text { ¿ } \\
\Sigma\end{array}$ & के & 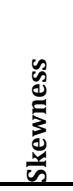 & 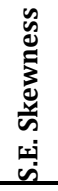 & 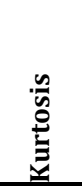 & 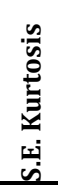 & $\underset{\Xi}{\Xi}$ & 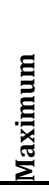 & $\stackrel{\vec{s}}{\stackrel{\Delta}{\Delta}}$ \\
\hline Curious & 142 & 2.49 & 2.00 & 1 & 1.82 & 1.05 & .20 & .04 & .40 & 1 & 7 & $-9.91^{* * *}$ \\
\hline Friendly & 142 & 2.60 & 2.00 & 1 & 1.89 & .91 & .20 & -.36 & .40 & 1 & 7 & $-8.81^{* * *}$ \\
\hline Active & 142 & 2.73 & 2.00 & 1 & 1.97 & .92 & .20 & -.36 & .40 & 1 & 7 & $-7.66^{* * *}$ \\
\hline Fun-loving & 142 & 2.76 & 2.00 & 1 & 1.97 & .82 & .20 & -.54 & .40 & 1 & 7 & $-7.51^{* * *}$ \\
\hline Even-tempered & 142 & 2.82 & 2.00 & 1 & 1.81 & .74 & .20 & -.42 & .40 & 1 & 7 & $-7.74^{* * *}$ \\
\hline Nervous & 142 & 2.82 & 2.00 & 1 & 1.90 & .80 & .20 & -.43 & .40 & 1 & 7 & $-7.39 * * *$ \\
\hline Contented & 142 & 3.04 & 3.00 & 1 & 1.97 & .58 & .20 & -.82 & .40 & 1 & 7 & $-5.84^{* * *}$ \\
\hline Jealous & 142 & 3.08 & 3.00 & 1 & 1.97 & .61 & .20 & -.81 & .40 & 1 & 7 & $-5.58^{* * *}$ \\
\hline Impatient & 142 & 3.10 & 3.00 & 1 & 1.94 & .60 & .20 & -.72 & .40 & 1 & 7 & $-5.55^{* * *}$ \\
\hline Warm & 142 & 3.11 & 3.00 & 1 & 2.00 & .54 & .20 & -1.00 & .40 & 1 & 7 & $-5.32^{* * *}$ \\
\hline Shy & 142 & 3.13 & 3.00 & 1 & 1.95 & .57 & .20 & -.84 & .40 & 1 & 7 & $-5.29^{* * *}$ \\
\hline Impulsive & 142 & 3.15 & 2.50 & 1 & 2.07 & .60 & .20 & -.93 & .40 & 1 & 7 & $-4.91^{* * *}$ \\
\hline High-strung & 142 & 3.15 & 3.00 & 1 & 2.08 & .56 & .20 & -.94 & .40 & 1 & 7 & $-4.85^{* * *}$ \\
\hline Timid & 142 & 3.18 & 3.00 & 1 & 1.96 & .61 & .20 & -.66 & .40 & 1 & 7 & $-5.01^{* * *}$ \\
\hline Sensitive & 142 & 3.23 & 3.00 & 1 & 2.11 & .48 & .20 & -1.08 & .40 & 1 & 7 & $-4.34^{* * *}$ \\
\hline Relaxed & 142 & 3.24 & 3.00 & 1 & 1.99 & .52 & .20 & -.84 & .40 & 1 & 7 & $-4.56^{* * *}$ \\
\hline Insecure & 142 & 3.28 & 3.00 & 1 & 2.02 & .51 & .20 & -.94 & .40 & 1 & 7 & $-4.24^{* * *}$ \\
\hline Receptive & 142 & 3.32 & 3.00 & 1 & 2.07 & .48 & .20 & -.99 & .40 & 1 & 7 & $-3.90^{* * *}$ \\
\hline Unemotional & 142 & 3.35 & 3.00 & 1 & 2.11 & .46 & .20 & -1.05 & .40 & 1 & 7 & $-3.66^{* * *}$ \\
\hline Emotional & 142 & 3.37 & 3.00 & 1 & 2.12 & .43 & .20 & -1.09 & .40 & 1 & 7 & $-3.52^{* * *}$ \\
\hline Uncooperative & 142 & 3.39 & 3.00 & 1 & 2.11 & .49 & .20 & -1.05 & .40 & 1 & 7 & $-3.47^{* * *}$ \\
\hline Passive & 142 & 3.45 & 3.00 & 1 & 1.98 & .35 & .20 & -.99 & .40 & 1 & 7 & $-3.31^{* * *}$ \\
\hline Comfortable & 142 & 3.49 & 3.00 & 1 & 2.07 & .40 & .20 & -1.09 & .40 & 1 & 7 & $-2.97^{* * *}$ \\
\hline Reserved & 142 & 3.66 & 4.00 & 1 & 2.07 & .22 & .20 & -1.17 & .40 & 1 & 7 & $-1.95^{* *}$ \\
\hline Passionate & 142 & 3.85 & 4.00 & 1 & 2.25 & .07 & .20 & -1.43 & .40 & 1 & 7 & -.78 \\
\hline Selfless & 142 & 3.99 & 4.00 & 4 & 2.08 & .02 & .20 & -1.18 & .40 & 1 & 7 & -.08 \\
\hline Mechanical & 142 & 4.00 & 4.00 & 7 & 2.17 & -.01 & .20 & -1.34 & .40 & 1 & 7 & -.00 \\
\hline Cold & 142 & 4.07 & 4.00 & 7 & 2.12 & .02 & .20 & -1.30 & .40 & 1 & 7 & .40 \\
\hline Hard-hearted & 142 & 4.15 & 4.00 & 7 & 2.17 & -.06 & .20 & -1.33 & .40 & 1 & 7 & .81 \\
\hline Helpful & 142 & 4.18 & 4.00 & 7 & 2.13 & -.08 & .20 & -1.27 & .40 & 1 & 7 & 1.03 \\
\hline Simple-minded & 142 & 4.25 & 4.00 & 7 & 2.19 & -.07 & .20 & -1.40 & .40 & 1 & 7 & 1.34 \\
\hline Polite & 142 & 4.42 & 4.00 & 7 & 2.16 & -.28 & .20 & -1.29 & .40 & 1 & 7 & $2.33^{* *}$ \\
\hline Frivolous & 142 & 4.45 & 4.00 & 7 & 2.15 & -.24 & .20 & -1.28 & .40 & 1 & 7 & $2.50^{* * *}$ \\
\hline Sympathetic & 142 & 4.49 & 4.00 & 7 & 2.04 & -.23 & .20 & -1.14 & .40 & 1 & 7 & $2.83^{* * *}$ \\
\hline Humble & 142 & 4.51 & 5.00 & 7 & 2.10 & -.28 & .20 & -1.19 & .40 & 1 & 7 & $2.88^{* * *}$ \\
\hline Ignorant & 142 & 4.63 & 5.00 & 7 & 2.27 & -.38 & .20 & -1.39 & .40 & 1 & 7 & $3.28^{* * *}$ \\
\hline Irresponsible & 142 & 4.63 & 5.00 & 7 & 2.24 & -.34 & .20 & -1.37 & .40 & 1 & 7 & $3.37^{* * *}$ \\
\hline Imaginative & 142 & 4.68 & 5.00 & 7 & 2.10 & -.42 & .20 & -1.18 & .40 & 1 & 7 & $3.87^{* * *}$ \\
\hline Rude & 142 & 4.72 & 5.00 & 7 & 2.21 & -.50 & .20 & -1.18 & .40 & 1 & 7 & $3.87^{* * *}$ \\
\hline Disorganized & 142 & 4.73 & 5.00 & 7 & 2.22 & -.47 & .20 & -1.24 & .40 & 1 & 7 & $3.90^{* * *}$ \\
\hline Thorough & 142 & 4.74 & 5.00 & 7 & 2.08 & -.44 & .20 & -1.13 & .40 & 1 & 7 & $4.25^{* * *}$ \\
\hline Logical & 142 & 5.00 & 6.00 & 7 & 2.08 & -.70 & .20 & -.82 & .40 & 1 & 7 & $5.74 * * *$ \\
\hline
\end{tabular}


Table 3. Descriptive statistics and one-sample t-test against the middle point of the scale (4) of the Human Uniqueness dimension (Cont.)

\begin{tabular}{|c|c|c|c|c|c|c|c|c|c|c|c|c|}
\hline & $z$ & $\sum_{\Sigma}^{\tilde{\Xi}}$ & 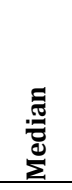 & 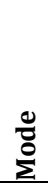 & के & 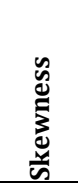 & 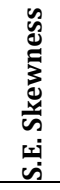 & 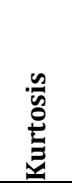 & 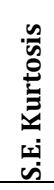 & $\underset{\Xi}{\Xi}$ & 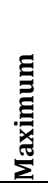 & $\stackrel{\vec{s}}{\stackrel{\Delta}{\Delta}}$ \\
\hline Refined & 142 & 5.01 & 5.50 & 7 & 2.02 & -.61 & .20 & -.92 & .40 & 1 & 7 & $5.97^{* * *}$ \\
\hline Superficial & 142 & 5.05 & 6.00 & 7 & 2.05 & -.70 & .20 & -.79 & .40 & 1 & 7 & $6.10^{* * *}$ \\
\hline Analytic & 142 & 5.06 & 6.00 & 7 & 2.00 & -.62 & .20 & -.92 & .40 & 1 & 7 & $6.31^{* * *}$ \\
\hline Conscientious & 142 & 5.07 & 5.50 & 7 & 2.01 & -.65 & .20 & -.84 & .40 & 1 & 7 & $6.36^{* * *}$ \\
\hline Rational & 142 & 5.10 & 6.00 & 7 & 2.14 & -.83 & .20 & -.73 & .40 & 1 & 7 & $6.10^{* * *}$ \\
\hline Ambitious & 142 & 5.21 & 6.00 & 7 & 1.99 & -.73 & .20 & -.83 & .40 & 1 & 7 & $7.27^{* * *}$ \\
\hline Broadminded & 142 & 5.29 & 6.00 & 7 & 1.94 & -.93 & .20 & -.30 & .40 & 1 & 7 & $7.90^{* * *}$ \\
\hline Stingy & 142 & 5.43 & 6.00 & 7 & 1.92 & -1.01 & .20 & -.26 & .40 & 1 & 7 & $8.88^{* * *}$ \\
\hline Sophisticated & 142 & 5.51 & 6.00 & 7 & 1.72 & -1.05 & .20 & .24 & .40 & 1 & 7 & $10.44^{* * *}$ \\
\hline Educated & 142 & 5.89 & 7.00 & 7 & 1.70 & -1.64 & .20 & 1.74 & .40 & 1 & 7 & $13.22^{* * *}$ \\
\hline
\end{tabular}

${ }^{*} p<0.1 ;{ }^{* *} p \leq 0.05 ;{ }^{* * *} p \leq 0.01$

Human Nature Dimension. Descriptive statistics and one sample t-tests are presented in Table 4. As with the other dimensions, all trait ratings ranged in all scale points. The lowest Human Nature rated trait was Rude, and the highest rated trait was Imaginative. There were 16 mismatched traits; traits that were originally high in Human Nature, but that in our sample rated as low: Frivolous, Irresponsible, Selfless, Jealous, High-strung, Ambitious, Insecure, Analytic, Helpful, Impatient, Friendly, Receptive, Nervous, Shy and Fun-loving. Furthermore, one trait originally was considered as low in Human Nature, but rated as high in Human nature in the present study (Even-tempered).

Table 4. Descriptive statistics and one-sample t-test against the middle point of the scale (4) of the Human Nature dimension.

\begin{tabular}{|c|c|c|c|c|c|c|c|c|c|c|c|c|}
\hline & $z$ & $\sum_{\Sigma}^{\tilde{\Xi}}$ & 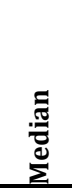 & $\frac{0}{\tilde{c}}$ & के & 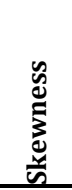 & 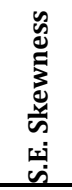 & 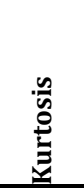 & 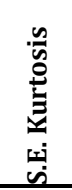 & $\stackrel{\Xi}{\Xi}$ & 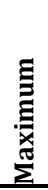 & 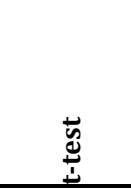 \\
\hline Rude & 102 & 2.26 & 2.00 & 1 & 1.73 & 1.58 & 0.24 & 1.75 & 0.47 & 1 & 7 & $-10.10^{* * *}$ \\
\hline Ignorant & 102 & 2.45 & 2.00 & 1 & 1.67 & 1.20 & 0.24 & 0.81 & 0.47 & 1 & 7 & $-9.34^{* * *}$ \\
\hline Refined & 102 & 2.72 & 2.00 & 1 & 1.64 & 0.88 & 0.24 & 0.14 & 0.47 & 1 & 7 & $-7.89^{* * *}$ \\
\hline Uncooperative & 102 & 2.81 & 3.00 & 1 & 1.53 & 0.54 & 0.24 & -0.33 & 0.47 & 1 & 7 & $-7.81^{* * *}$ \\
\hline Polite & 102 & 2.85 & 2.00 & 1 & 1.87 & 0.82 & 0.24 & -0.21 & 0.47 & 1 & 7 & $-6.20^{* * *}$ \\
\hline Sophisticated & 102 & 2.88 & 2.00 & 1 & 1.80 & 0.75 & 0.24 & -0.36 & 0.47 & 1 & 7 & $-6.26^{* * *}$ \\
\hline Frivolous & 102 & 2.94 & 3.00 & 1 & 1.71 & 0.66 & 0.24 & -0.19 & 0.47 & 1 & 7 & $-6.27^{* * *}$ \\
\hline Irresponsible & 102 & 3.01 & 3.00 & 3 & 1.68 & 0.67 & 0.24 & -0.10 & 0.47 & 1 & 7 & $-5.95^{* * *}$ \\
\hline Educated & 102 & 3.01 & 2.50 & 1 & 1.99 & 0.81 & 0.24 & -0.44 & 0.47 & 1 & 7 & $-5.03^{* * *}$ \\
\hline Unemotional & 102 & 3.05 & 3.00 & 1 & 1.84 & 0.57 & 0.24 & -0.70 & 0.47 & 1 & 7 & $-5.21^{* * *}$ \\
\hline Superficial & 102 & 3.14 & 3.00 & 1 & 1.82 & 0.61 & 0.24 & -0.54 & 0.47 & 1 & 7 & $-4.79^{* * *}$ \\
\hline Hard-hearted & 102 & 3.18 & 3.00 & 1 & 1.82 & 0.57 & 0.24 & -0.64 & 0.47 & 1 & 7 & $-4.57^{* * *}$ \\
\hline Stingy & 102 & 3.19 & 3.00 & 1 & 2.01 & 0.58 & 0.24 & -0.93 & 0.47 & 1 & 7 & $-4.09^{* * *}$ \\
\hline Selfless & 102 & 3.29 & 3.00 & 3 & 1.58 & 0.32 & 0.24 & -0.41 & 0.47 & 1 & 7 & $-4.52^{* * *}$ \\
\hline Disorganized & 102 & 3.34 & 3.50 & 4 & 1.72 & 0.28 & 0.24 & -0.59 & 0.47 & 1 & 7 & $-3.86^{* * *}$ \\
\hline Cold & 102 & 3.39 & 3.00 & 1 & 1.84 & 0.33 & 0.24 & -0.85 & 0.47 & 1 & 7 & $-3.33^{* * *}$ \\
\hline Relaxed & 102 & 3.44 & 3.00 & 3 & 1.45 & 0.10 & 0.24 & -0.09 & 0.47 & 1 & 7 & $-3.89 * * *$ \\
\hline
\end{tabular}


Table 4. Descriptive statistics and one-sample t-test against the middle point of the scale (4) of the Human Nature dimension (Cont.)

\begin{tabular}{|c|c|c|c|c|c|c|c|c|c|c|c|c|}
\hline & $z$ & $\sum_{\Sigma}^{\Xi \Xi}$ & 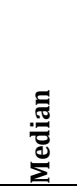 & $\begin{array}{l}0 \\
\stackrel{0}{0} \\
\Sigma\end{array}$ & के & \begin{tabular}{l}
$\tilde{d}$ \\
\multirow{2}{*}{} \\
$\frac{y}{b}$
\end{tabular} & 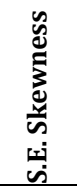 & $\stackrel{n}{\mathscr{n}}$ & 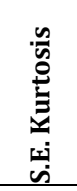 & $\underset{\Xi}{\Xi}$ & 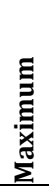 & 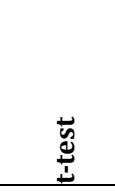 \\
\hline Jealous & 102 & 3.52 & 3.00 & 1 & 1.96 & 0.27 & 0.24 & -1.03 & 0.47 & 1 & 7 & $-2.47^{* *}$ \\
\hline Humble & 102 & 3.55 & 3.50 & 4 & 1.92 & 0.31 & 0.24 & -0.92 & 0.47 & 1 & 7 & $-2.37^{* *}$ \\
\hline Contented & 102 & 3.55 & 4.00 & 4 & 1.69 & 0.21 & 0.24 & -0.55 & 0.47 & 1 & 7 & $-2.70^{* * *}$ \\
\hline Broadminded & 102 & 3.62 & 4.00 & 4 & 1.79 & 0.29 & 0.24 & -0.66 & 0.47 & 1 & 7 & $-2.16^{* *}$ \\
\hline Conscientious & 102 & 3.62 & 4.00 & 4 & 1.85 & 0.25 & 0.24 & -0.82 & 0.47 & 1 & 7 & $-2.09 * *$ \\
\hline Timid & 102 & 3.63 & 4.00 & 4 & 1.71 & 0.17 & 0.24 & -0.66 & 0.47 & 1 & 7 & $-2.20^{* *}$ \\
\hline Mechanical & 102 & 3.63 & 4.00 & 4 & 1.67 & 0.10 & 0.24 & -0.66 & 0.47 & 1 & 7 & $-2.25^{* *}$ \\
\hline Passive & 102 & 3.67 & 4.00 & 4 & 1.67 & 0.14 & 0.24 & -0.56 & 0.47 & 1 & 7 & $-2.02^{* *}$ \\
\hline High-strung & 102 & 3.69 & 4.00 & 4 & 1.77 & 0.22 & 0.24 & -0.74 & 0.47 & 1 & 7 & $-1.79 *$ \\
\hline Ambitious & 102 & 3.71 & 4.00 & 4 & 1.96 & 0.01 & 0.24 & -1.13 & 0.47 & 1 & 7 & -1.51 \\
\hline Comfortable & 102 & 3.72 & 4.00 & 4 & 1.59 & 0.17 & 0.24 & -0.30 & 0.47 & 1 & 7 & $-1.80^{*}$ \\
\hline Thorough & 102 & 3.73 & 4.00 & 4 & 1.92 & 0.11 & 0.24 & -1.06 & 0.47 & 1 & 7 & -1.44 \\
\hline Insecure & 102 & 3.75 & 4.00 & 4 & 1.82 & 0.01 & 0.24 & -0.90 & 0.47 & 1 & 7 & -1.41 \\
\hline Analytic & 102 & 3.75 & 4.00 & 4 & 1.78 & 0.07 & 0.24 & -0.80 & 0.47 & 1 & 7 & -1.39 \\
\hline Simple-minded & 102 & 3.75 & 4.00 & 4 & 1.91 & 0.13 & 0.24 & -1.02 & 0.47 & 1 & 7 & -1.30 \\
\hline Helpful & 102 & 3.76 & 4.00 & 4 & 1.71 & -0.04 & 0.24 & -0.61 & 0.47 & 1 & 7 & -1.39 \\
\hline Impatient & 102 & 3.77 & 3.00 & 3 & 1.77 & 0.23 & 0.24 & -0.83 & 0.47 & 1 & 7 & -1.28 \\
\hline Friendly & 102 & 3.88 & 4.00 & 4 & 1.81 & -0.10 & 0.24 & -0.88 & 0.47 & 1 & 7 & -0.66 \\
\hline Receptive & 102 & 3.88 & 4.00 & 4 & 1.68 & -0.20 & 0.24 & -0.74 & 0.47 & 1 & 7 & -0.71 \\
\hline Nervous & 102 & 3.90 & 4.00 & 4 & 1.92 & 0.13 & 0.24 & -0.97 & 0.47 & 1 & 7 & -0.52 \\
\hline Shy & 102 & 3.97 & 4.00 & 4 & 1.74 & 0.00 & 0.24 & -0.83 & 0.47 & 1 & 7 & -0.17 \\
\hline Fun-loving & 102 & 3.98 & 4.00 & 4 & 1.89 & -0.14 & 0.24 & -0.98 & 0.47 & 1 & 7 & -0.10 \\
\hline Even-tempered & 102 & 4.02 & 4.00 & 3 & 1.63 & 0.09 & 0.24 & -0.42 & 0.47 & 1 & 7 & 0.12 \\
\hline Warm & 102 & 4.02 & 4.00 & 4 & 1.69 & -0.19 & 0.24 & -0.65 & 0.47 & 1 & 7 & 0.12 \\
\hline Sympathetic & 102 & 4.03 & 4.00 & 4 & 1.90 & -0.07 & 0.24 & -0.89 & 0.47 & 1 & 7 & 0.16 \\
\hline Reserved & 102 & 4.05 & 4.00 & 4 & 1.68 & 0.05 & 0.24 & -0.47 & 0.47 & 1 & 7 & 0.29 \\
\hline Passionate & 102 & 4.16 & 4.00 & 4 & 1.91 & -0.20 & 0.24 & -1.03 & 0.47 & 1 & 7 & 0.83 \\
\hline Logical & 102 & 4.23 & 4.00 & 4 & 1.86 & -0.08 & 0.24 & -0.86 & 0.47 & 1 & 7 & 1.23 \\
\hline Impulsive & 102 & 4.31 & 4.00 & 4 & 1.77 & -0.13 & 0.24 & -0.88 & 0.47 & 1 & 7 & $1.79 *$ \\
\hline Active & 102 & 4.55 & 4.00 & 4 & 1.56 & -0.32 & 0.24 & -0.27 & 0.47 & 1 & 7 & $3.56^{* * *}$ \\
\hline Sensitive & 102 & 4.59 & 5.00 & 4 & 1.77 & -0.43 & 0.24 & -0.54 & 0.47 & 1 & 7 & $3.37^{* * *}$ \\
\hline Rational & 102 & 4.75 & 5.00 & 7 & 1.95 & -0.53 & 0.24 & -0.83 & 0.47 & 1 & 7 & $3.86^{* * *}$ \\
\hline Curious & 102 & 4.77 & 5.00 & 7 & 1.86 & -0.56 & 0.24 & -0.64 & 0.47 & 1 & 7 & $4.22^{* * *}$ \\
\hline Emotional & 102 & 4.79 & 5.00 & 4 & 1.68 & -0.40 & 0.24 & -0.52 & 0.47 & 1 & 7 & $4.78^{* * *}$ \\
\hline Imaginative & 102 & 4.89 & 5.00 & 7 & 1.88 & -0.60 & 0.24 & -0.65 & 0.47 & 1 & 7 & $4.79 * * *$ \\
\hline
\end{tabular}

${ }^{*} p<0.1 ;{ }^{* *} p \leq 0.05 ;{ }^{* * *} p \leq 0.01$

\section{Paired-Sample t-tests}

Paired-sample t-tests were conducted in order to assess distinctiveness and similarity of the groups, regarding their Human Nature and Human Uniqueness ratings. Results are presented in Table 5. 
Table 5. Grouping, descriptive statistics, consistency measures and t-test of the quadrants

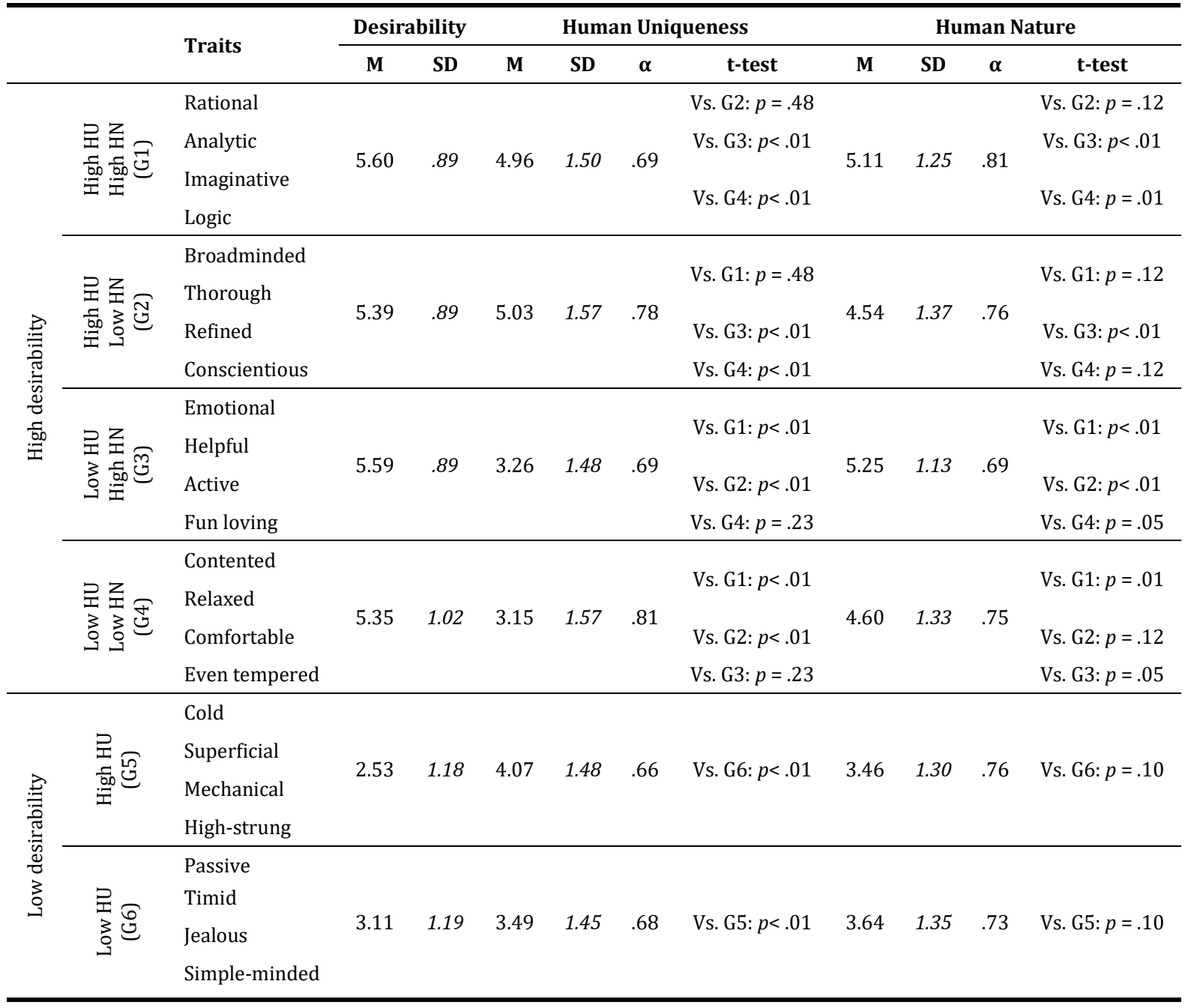

Positive Desirability Traits. Four groups of highly desirable traits, each containing four traits, were computed, based on their rated Human Nature and Human Uniqueness. Traits were chosen based on their mean ratings. The grouping of the traits, their descriptive statistics and internal consistency measures are presented in Table 5.

The first group is high in HU and HN ratings, consisting of the traits Rational, Analytic, Imaginative and Logical. The second group, high in HU and low in HN, entails the traits Broadminded, Thorough, Refined and Conscientious. The third group is low in HU and high in HN, and contains the traits Emotional, Helpful, Active and Fun-loving. Finally, the fourth group is low in HU and HN, containing the traits Contented, Relaxed, Comfortable and Even-tempered.

Regarding the results of the t-tests on the HU dimension (Table 6), the means of the two groups with traits high in human uniqueness - groups 1 and 2 - were not significantly different from one another, but were significantly different from the mean of the groups with traits low in human uniqueness - groups 3 and 4; these two groups did not differ between themselves.

As for the results of the t-tests concerning the HN dimension, the means of the groups high in human nature - groups 1 and 3 - were not significantly different between themselves, but were significantly different from the groups with traits low in human nature - groups 2 and 4; these last groups did not differ significantly between themselves. All groups present good internal consistency indices.

Negative desirability traits. As the HN ratings were negatively skewed in relation to the middle point, we could not find four groups based on $\mathrm{HU}$ and $\mathrm{HN}$ ratings. Therefore, we present, for the negative desirability traits, a measure of HU (Table 5).

The first group, low in HU, consists of the traits Passive, Timid, Jealous and Simple-minded; the second group is high in HU and contains the traits Cold, Superficial, Mechanical and High-strung. The groups differ significantly in HU, but not in HN. Both groups presented good internal consistency $(\alpha<0.7)$. 


\section{DISCUSSION}

Past research has highlighted the need to recognize dehumanization as an everyday social phenomenon (Haslam, 2006) with implications for interpersonal and intergroup contexts (Bastian et al., 2014; Haslam \& Loughnan, 2014). The dual model of humanness (and its corresponding forms of dehumanization) is of extreme relevance in the dehumanization literature because it added another dimension in which humanness can be attributed to the self and (in and out) groups. More specifically, the trait-based measure of humanness allows to assess cultural variability in the characterization of one's group as well as other groups (Bain, 2014). Research on dehumanization shows the existence of cultural differences in the proposed two dimensions; for example, when asked to name traits that define what means to be human, Italian participants named traits high in both dimensions, Australian participants use traits high on human nature and low on human uniqueness, and Chinese participants presented the opposite pattern (Bain, Vaes, Kashima, Haslam, and Guan, 2012). These are examples of cultural specificities in how groups attribute human traits to themselves and other groups and define one dimension as more or less relevant than the other depending on their cultural inheritance. This stresses how important it is to validate traits for a specific culture and one of its most important expressions, language.

An instrument capable of assessing this phenomenon, however, had not yet been validated for the Portuguese context. To fill this gap in the literature, this study aimed to provide a culturally adapted measure to study the two senses of dehumanization in the Portuguese context. To reach this goal we referred to the methodology employed in the development of a set of dehumanization traits proposed by Haslam and colleagues (2005)..

Overall, the traits examined in this study are, to some extent, in accordance with those used previously by Haslam and colleagues and our results support the dual model of humanness proposed by the authors (Haslam et al., 2005; Haslam \& Bain, 2007). We can conclude that these traits are valid to assess dehumanization in the Portuguese context. It is important to note, however, that some traits did not match to the group of traits proposed by previous studies.

The first group of traits we found, consisting of high in HU and HN ratings were Rational, Analytic, Imaginative and Logical. Haslam and Bain (2007) found similar traits such as Analytic and Imaginative, but also other positive ones that we did not find, such as Passionate and Sympathetic; the traits in this group correspond to the humanization quadrant proposed by Li, Leidner and Castano (2014). Individuals or groups that are described as rational, analytic, logical and imaginative are capable of planning and logical reasoning, which are agentic uniquely human characteristics, and are also capable of experiential depth, a core human characteristic.

The second group of traits corresponded to those high in HU but low in HN and entailed the traits: Broadminded, Thorough, Refined and Conscientious. This is somewhat similar to the traits found by Haslam and Bain (2007) in this quadrant, although they also found Humble and Polite to be in this taxonomy. This quadrant reflects a mechanistic dehumanization, as it represents people with high competence and agency, but lacking in warmth and experiential depth. The third group was low in HU but high in HN, and contained the traits Emotional, Helpful, Active and Fun-loving. It corroborates the animalistic form of dehumanization, considering that it comprises traits high in warmth and experiential depth, but low in agency. Haslam and Bain (2007) found positive traits such as Helpful, Active and Funloving but also Curious, Friendly. Finally, the fourth group was low in HU and HN, and comprised the following traits: Contented, Relaxed, Comfortable and Even-tempered. Haslam and Bain (2007) found the same positive traits with the addition of Selfless, making up a sense of total dehumanization: a lack of both agency and experiential depth.

Regarding negative traits, however, we were only able to discriminate between high and low in the $\mathrm{HU}$ dimension, but not $\mathrm{HN}$, as the answers to this dimension were very condensed around the mean point of the scale, and did not discriminate a high or low sense of Human Nature. These findings may, to some extent, mirror the pattern of findings found by Bain and colleagues (2012), where both a Chinese and an Italian sample placed more emphasis on the traits related to HU than to HN. These authors suggested that the higher emphasis on HU could be related to the cultural influence (e.g., exportation of philosophy and art) on the world that these countries had historically (as opposed to the emphasis given to HN traits given by an Australian sample, considering Australia a "younger country" with less cultural influence on the world).

The negative traits we found that were low in HU were: Passive, Timid, Simple-minded, and Jealous. All these traits matched the negative high HU traits that Haslam and Bain (2007) proposed. Our findings regarding high HU negative traits - Cold, Superficial, Mechanical and High-strung - did not correspond to what Haslam and Bain (2007) found. This mismatch can be related to the fact that these traits (i.e., Cold, Superficial and Mechanical) were added to those proposed by Haslam and Bain (2007) based on Bastian, Jetten and Radke (2012). Nonetheless, these traits adjusted well to the concept of human uniqueness, as 
these traits are socially acquired, refer to higher-order functions and secondary emotions, thus distinguishing humans from animals. Furthermore, Li and colleagues (2014), state that the attribution of secondary emotions is fundamental to the concept of humanity; individuals or groups that are denied Human Uniqueness are not considered sophisticated or well acculturated.

Generally, the internal consistency of the clusters was acceptable to good, the inter-item correlations were not bellow the lower value, which attest the fidelity of the measure (Piedmont, 2014), and only three clusters presented a value of inter-item correlations above the cut-off value.

\section{Limitations of the study and future research}

In general, the grouping of traits obtained seemed to fit rather well with the grouping that Haslam and Bain (2007) proposed. Moreover, each group of positive traits adequately represented the quadrants' corresponding agency and competence as well as warmth and experiential depth. However, we were not able to identify traits that could operationalize the eight expected combinations of the three dimensions: desirability, human uniqueness and human nature. Ratings of the less desirable traits lacked the dispersion necessary to differentiate between high and low Human nature. This seems to be specific to these data, given that Haslam and Bain (2007) reported a similar dispersion for all dimensions.

Another limitation is related to the fact that the stability of the instrument was not assessed. Future studies should try to examine how this measure performs over time. Also, convergent and divergent validity was not examined. It would be important in the future to explore the association between these traits and other important variables for the study of dehumanization - for example, by investigating the association between these measures and other constructs that are theoretically associated with dehumanization, such as perceived socioeconomic status on intergroup biases.

Notwithstanding the fact that the negative traits did not hold a result such as the one proposed by Haslam and colleagues (2005), and the limitations stated above, we believe that this study provides a culturally adapted measure of human uniqueness controlling for human nature (as all its traits are rated as reflecting average levels of human nature), with good psychometric properties. This represents a stepping stone in culturally adapting and validating the dehumanization measure proposed by Haslam and colleagues (2005), adding important insights to the study of dehumanization within the Portuguese context and improving research on the two dimensions of humanness in the Portuguese setting.

\section{REFERENCES}

Bain, P. G. (2014). The structure and content of the human category, and its implications for understanding dehumanization. In P. G. Bain, J. Vaes, \& J.-P. Leyens (Eds.), Humanness and Dehumanization (pp. 227253). Psychology Press.

Bain, P., Vaes, J., Kashima, Y., Haslam, N., \& Guan, Y. (2012). Folk conceptions of humanness beliefs about distinctive and core human characteristics in Australia, Italy, and China. Journal of Cross-Cultural Psychology, 43(1), 53-58.

Bastian, B., \& Haslam, N. (2010). Excluded from humanity: The dehumanizing effects of social ostracism. Journal of Experimental Social Psychology, 46(1), 107-113. https://doi.org/10.1016/j.jesp.2009.06.022

Bastian, B., Jetten, J., \& Haslam, N. (2014). An interpersonal perspective on dehumanization. In P. G. Bain, J. Vaes, \& J.-P. Leyens (Eds.), Humanness and Dehumanization (pp. 205-224). Psychology Press.

Bastian, B., Jetten, J., \& Radke, H. R. (2012). Cyber-dehumanization: Violent video game play diminishes our humanity. Journal of Experimental Social Psychology, 48(2), 486-491.

Christoff, K. (2014). Dehumanization in organizational settings: Some scientific and ethical considerations. Frontiers in Human Neuroscience, 8. https://doi.org/10.3389/fnhum.2014.00748

Church, A. T., Katigbak, M. S., Reyes, J. A. S., Salanga, M. G. C., Miramontes, L. A., \& Adams, N. B. (2008). Prediction and cross-situational consistency of daily behavior across cultures: Testing trait and cultural psychology perspectives. Journal of Research in Personality, 42(5), 1199-1215. https://doi.org/10.1016/j.jrp.2008.03.007

Costa, P. T., \& McCrae, R. R. (1992). Normal personality assessment in clinical practice: The NEO Personality Inventory. Psychological Assessment, 4(1), 5.

Deuthsche Film Gesellschaft (Producer) \& Hippler, F. (Director), (1940), Der Ewig Jude [documentary]. Germany: Terra

Diniz, E., Bernardes, S. F., \& Castro, P. (2019). Self- and other-dehumanization processes in health-related contexts: A Critical review of the literature. Review of General Psychology, 23(4), 475-495. https://doi.org/10.1177/1089268019880889 
Dodge, N., \& Chapman, R. (2018). Investigating recruitment and completion mode biases in online and door to door electronic surveys. International Journal of Social Research Methodology, 21(2), 149-163. https://doi.org/10.1080/13645579.2017.1336596

Haque, O. S., \& Waytz, A. (2012). Dehumanization in medicine: Causes, solutions, and functions. Perspectives on Psychological Science, 7(2), 176-186.

Haslam, N. (2006). Dehumanization: An integrative review. Personality and Social Psychology Review, 10(3), 252-264.

Haslam, N., \& Bain, P. (2007). Humanizing the self: Moderators of the attribution of lesser humanness to others. Personality and Social Psychology Bulletin, 33(1), 57-68.

Haslam, N., Bain, P., Douge, L., Lee, M., \& Bastian, B. (2005). More human than you: attributing humanness to self and others. Journal of Personality and Social Psychology, 89(6), 937.

Haslam, N., Bastian, B., \& Bissett, M. (2004). Essentialist beliefs about personality and their implications. Personality and Social Psychology Bulletin, 30(12), 1661-1673.

Haslam, N., \& Loughnan, S. (2014). Dehumanization and infrahumanization. Annual Review of Psychology, 65, 399-423.

Haslam, N., Loughnan, S., Kashima, Y., \& Bain, P. (2009). Attributing and denying humanness to others. European Review of Social Psychology, 19(1), 55-85.

Leyens, J. P., Demoulin, S., Vaes, J., Gaunt, R., \& Paladino, M. P. (2007). Infra-humanization: The wall of group differences. Social Issues and Policy Review, 1(1), 139-172.

Leyens, J. P., Paladino, P. M., Rodriguez-Torres, R., Vaes, J., Demoulin, S., Rodriguez-Perez, A., \& Gaunt, R. (2000). The emotional side of prejudice: The attribution of secondary emotions to ingroups and outgroups. Personality and Social Psychology Review, 4(2), 186-197.

Leyens, J. P., Rodriguez-Perez, A., Rodriguez-Torres, R., Gaunt, R., Paladino, M. P., Vaes, J., \& Demoulin, S. (2001). Psychological essentialism and the differential attribution of uniquely human emotions to ingroups and outgroups. European Journal of Social Psychology, 31(4), 395-411.

Li, M., Leidner, B., \& Castano, E. (2014). Toward a comprehensive taxonomy of dehumanization: Integrating two senses of humanness, mind perception theory, and stereotype content model. TPM-Testing, Psychometrics, Methodology in Applied Psychology, 21(3), 285-300.

Lima, M. E. O., \& Vala, J. (2004). Sucesso social, branqueamento e racismo. Psicologia: Teoria e Pesquisa, 20(1), 11-19. https://doi.org/10.1590/S0102-37722004000100003

Louceiro, A. (2016). Dehumanization revisited: The humanization of ingroup and outgroup members depends on the perception of social relatedness. ISCTE-IUL, Lisbon.

McCrae, R. R., \& Costa Jr., P. T. (1997). Personality trait structure as a human universal. American Psychologist, 52(5), 509-516. https://doi.org/10.1037/0003-066X.52.5.509

Miranda, M., Gouveia-Pereira, M., \& Vaes, J. (2014). When in Rome. Identification and acculturation strategies among minority members moderate the dehumanisation of the majority outgroup. European Journal of Social Psychology, 44(4), 327-336.

Ngeze, H. (1993, February). Editorial: A cockroach (Inyenzi) cannot bring forth a butterfly. Kangura, 40.

Piedmont, R. L. (2014). Inter-item correlations. In A. C. Michalos (Ed.), Encyclopedia of Quality of Life and Well-Being Research (pp. 3303-3304). Springer Netherlands. https://doi.org/10.1007/978-94-0070753-5_1493

Reynolds, E. (2012, December 11). 'Beast of Kavos' given record 52-year sentence for raping more than seven British tourists at knifepoint in Corfu. The Daily Mail. http://www.dailymail.co.uk/

Schwartz, S. H. (1992). Universals in the content and structure of values: Theoretical advances and empirical tests in 20 countries. In M. P. Zanna (Ed.), Advances in Experimental Social Psychology (Vol. 25, pp. 1-65). https://doi.org/10.1016/S0065-2601(08)60281-6

Vaes, J., Leyens, J.-P., Paladino, M. P., \& Miranda, M. P. (2012). We are human, they are not: Driving forces behind outgroup dehumanisation and the humanisation of the ingroup. European Review of Social Psychology, 23(1), 64-106. https://doi.org/10.1080/10463283.2012.665250

Viki, G. T., Winchester, L., Titshall, L., Chisango, T., Pina, A., \& Russell, R. (2006). Beyond secondary emotions: The infrahumanization of outgroups using human-related and animal-related words. Social Cognition, 24(6), 753-775. https://doi.org/10.1521/soco.2006.24.6.753

Wing, N. (2013, July 26). Ken Cuccinelli once compared immigration policy to pest control, exterminating rats. The Huffington Post. http://www.huffingtonpost.com/

Wortham, J. (2012, March 12). Use of homeless as internet hot spots backfires on marketer. The New York Times. http://www.nytimes.com 
Trait-based Measure of Dehumanization

Historial do artigo

Recebido 05/2019

Aceite $\quad 02 / 2020$

Publicado $\quad 08 / 2020$ 